Article

\title{
In the Shadow of Cormorants: Succession of Avian Colony Affects Selected Groups of Ground Dwelling Predatory Arthropods
}

\author{
Ondřej Machač ${ }^{1}$, Povilas Ivinskis ${ }^{2}$, Jolanta Rimšaitè ${ }^{2}$, Ondřej Horňák ${ }^{1}$ and Ivan Hadrián Tuf ${ }^{1, *}$ \\ 1 Department of Ecology and Environmental Sciences, Faculty of Science, Palacký University Olomouc, \\ Šlechtitelů 27, 77900 Olomouc, Czech Republic; machac.ondra@seznam.cz (O.M.); hornak.o@seznam.cz (O.H.) \\ 2 Institute of Ecology, Nature Research Centre, Akademijos 2, 08412 Vilnius, Lithuania; ivinskis@ekoi.lt (P.I.); \\ jolanta.rimsaite@gamtc.lt (J.R.) \\ * Correspondence: ivan.tuf@upol.cz; Tel.: +420-777262924
}

check for updates

Citation: Machač, O.; Ivinskis, P.; Rimšaitè, J.; Horňák, O.; Tuf, I.H. In the Shadow of Cormorants: Succession of Avian Colony Affects Selected Groups of Ground Dwelling Predatory Arthropods. Forests 2022, 13, 330. https://doi.org/10.3390/ f13020330

Academic Editor: Todd

S. Fredericksen

Received: 15 December 2021

Accepted: 10 February 2022

Published: 17 February 2022

Publisher's Note: MDPI stays neutral with regard to jurisdictional claims in published maps and institutional affiliations.

Copyright: (c) 2022 by the authors. Licensee MDPI, Basel, Switzerland. This article is an open access article distributed under the terms and conditions of the Creative Commons Attribution (CC BY) license (https:// creativecommons.org/licenses/by/ $4.0 /)$.

\begin{abstract}
Nesting of the great cormorants strongly influences terrestrial ecosystems by physical destruction of vegetation and chemical changes in the soil and around the nesting colonies. (2) We investigated spider, harvestmen, and centipede assemblages in different influenced plots (starting colony, active dense colony, and partly abandoned colony) in the biggest Lithuanian cormorant colony in pine woods on the shore of the Baltic Sea in the Curonian Spit National Park in Lithuania. Selected groups of ground dwelling predatory arthropods were collected by pitfall traps in 2012-2014. (3) We recorded a total of 4299 spider specimens (102 species), 451 harvestmen specimens ( 9 species), and 1537 centipede specimens ( 7 species). The coverage of moss and herb vegetation, mean Ellenberg value for light, bare ground without vegetation, and number of nests significantly influenced the abundance, species richness, and ecological groups of arthropod predators. (4) Active ground hunters represented by spider Trochosa terricola and centipede Lithobius forficatus were positively influenced by bare ground without vegetation and a higher density of nests, and negatively influenced by an increasing coverage of moss and herbs. The opposite effect was found for web builder spiders and less movable species, represented by dominant spider species Diplostyla concolor and harvestmen Nemastoma lugubre and Oligolophus tridens. (5) The results show how cormorant influence the forest vegetation structure and affect the abundance and species diversity of ground dwelling predatory arthropods.
\end{abstract}

Keywords: Araneae; Chilopoda; Opiliones; Phalacrocorax carbo; Curonian spit; nesting colony; Lithuania

\section{Introduction}

The great cormorant (Phalacrocorax carbo L.) is a common avian fish predator with global distribution, especially in the Northern Hemisphere [1]. Populations of great cormorants have recently been rising all over Europe [2,3]. Cormorants roost and breed in numerous colonies in peaceful localities close to lakes and river areas or on the sea coast [4]. Cormorant nests are usually on the tops of trees; up to 50 nests may be on one tree [2]. Nesting colonies are often reused for several years, but sometimes nesting trees are changed after one season [2,5]. Some colonies may have thousands of nesting individuals. Among the entire population of all species of coastal birds, cormorants demonstrate the greatest impact on their coastal terrestrial ecosystems [5].

Cormorants and other water birds strongly influence ecosystems both in and around the nesting colony [6,7]. One cormorant produces about $50 \mathrm{~g}$ of faeces per day [8] and over $80 \%$ of it is deposited beneath their roosts and nests [9]. Droppings increase the amount of nitrogen, phosphorus, and other nutrients in the soil [8,10]. These processes increase the acidity [11] and humidity of soil and have an impact on vegetation [12]. Cormorants affect ecosystems, especially herb, shrub, and tree vegetation growing in the 
colony. Trees and herb vegetation in dense and numerous colonies die or significantly recede [13], only nitrophilic species profit from it, e.g., Sambucus nigra L., Urtica dioica L., or some grasses [9]. The abundance and diversity of herbivorous insects in dense colonies also decrease, while other arthropod groups may be more abundant [14]. Dead trees change light conditions and pass more light to the undergrowth. Such changes can last for decades following colony abandonment [15]. Many droppings, remains from fish, and dead bodies of cormorant chicks in the nesting colonies attract carrion and dung-feeding invertebrates and their predators $[9,12,16,17]$. Different parts in the cormorant colony vary in physical conditions and herb coverage [18], as well as in species diversity and communities of small mammals $[19,20]$ and some groups of arthropods [12,14]. There is also a negative effect on spider diversity [21] and litter decomposition [22].

One of the biggest colonies of great cormorants and grey herons in Lithuania is in the Curonian Spit National Park near Juodkrante. In this colony, the first cormorant nests appeared in 1989 [23], and during our study, the breeding lowered by thousands of nesting cormorants in the colony.

Despite ground beetles, the main group of ground dwelling predatory arthropods are spiders (Araneae), harvestmen (Opiliones), and centipedes (Chilopoda). Spiders and harvestmen are understudied taxa in Lithuania, as until now, only 462 species were known [24,25]. In the Curonian Spit National Park, 228 species of spiders and 10 of harvestmen were found (Machač, unpubl. data). Besides this, 20 species of centipedes have been reported from Lithuania [26].

Assemblages of arachnids are strongly influenced by the vegetation structure [27], as well as their changes in succession [28-30] and light conditions via tree canopy openness [31]. Open young forest and clearings are inhabited by rather cursorial and other non-web building spiders, while old forests with undergrowth are inhabited instead by web builders [30,32]. Similarly, ground dwelling arachnids intensively react to microhabitat conditions such as light, moisture, temperature, vegetation structure, and litter, while landscape features are less important [29,33-36]. Spiders have evolved several predatory strategies resulting in many different functional roles, enabling the precise evaluation of the functional diversity of their communities [37].

In this study, we investigated how three-year long changes in vegetation (coverage, Ellenberg's indicator values for light, moisture, and nutrients), the presence of bare soil and cormorant nest density influenced assemblages of spiders, harvestmen, and centipedes in the cormorant colony in the Curonian Spit National Park in Lithuania.

\section{Materials and Methods}

The study was performed in one of the biggest colonies of great cormorants (Phalacrocorax carbo) with few tents of nests of grey herons (Ardea cinerea L.) on the shore of the Baltic Sea. This colony is situated in a pine forest in the Curonian Spit National Park in Lithuania near Juodkrante (centre of colony: $49^{\circ} 30^{\prime} 36.37^{\prime \prime} \mathrm{N}, 17^{\circ} 18^{\prime} 1.31^{\prime \prime}$ E). Sampling sites represented pine forest with herb and shrub undergrowth with different degrees of influence by bird nesting activities, during the investigation cormorants occupied about 3100 nests and the colony covered an area of 6.82 ha [23]. The climate is intermediate between marine and continental, the mean annual precipitation is about $700 \mathrm{~mm}$, and the mean annual temperatures range from $17.8^{\circ} \mathrm{C}$ in August to $-1.7^{\circ} \mathrm{C}$ in January and February [38].

The study was performed in 2012-2014 in the cormorant colony and surrounding forest. The colony was in the upper part of dune ridge to dune hollow. The upper parts were occupied by 110-year-old pine forest and slope terraces with an approximately 230-year-old forest. We chose four plots with different influences of cormorants:

- Plot A (starting colony)—new colony with an increasing number of nests. The predominant tree species in this area was Scots pine (Pinus sylvestris L.), with an average age of 119 years. Undergrowth was drying and sparse. In the shrub layer, rowan (Sorbus 
aucuparia L.) and common juniper (Juniperus communis L.) were dominant. Trees were alive, but their vitality decreased.

- Plot B (active colony) - epicenter of the colony with the highest density of nests on trees. Forest was strongly influenced by cormorants. Pine trees were dead or dying. Undergrowth was sparse and exposed to sunlight; huge spots of bare ground without vegetation were present. Nitrophilic species of plants dominated in the herb and shrubs layer with coverage of less than 10\% [39]. The dominant species in the shrub layer was elderberry (Sambucus racemosus L.).

- $\quad$ Plot C (abandoned colony) —old part of the colony, partly abandoned, and nest trees were almost absent. Dead trees without the bark were standing or fallen. Vegetation was partly recovering with shrubs, and herbal and moss layers. Nitrophilic plants were partly replaced by mesoeutrophic ruderal herbs and shrubs such as $S$. nigra. Pines were replaced by young Norway spruce (Picea abies L.), English oak (Quercus robur L.), and birch (Betula pubescens Ehrh.) [39].

- Plot D (control unaffected plot) - natural old-growth mixed pine forest with admixture birch (Betula humilis Schrank), maples (Acer platanoides L.), and linden (Tilia cordata Mill.), and with shrubs such as bird cherry (Prunus padus L.), currant (Ribes alpinum L.), raspberry (Rubus idaeus L.), and herb layers with nitrophilous species such as common nettle (U. dioica) and impatiens (Impatiens sp.).

The structure of vegetation coverage and vegetation changes on the study plots was taken from the botanical study done on this colony [18], where data of the coverage of trees, shrubs, and herb and moss vegetation from three squares $\left(100 \mathrm{~m}^{2}\right)$ in each sampling plot were analysed. Abiotic variables were derived from plant communities using by Ellenberg indicator values for humidity, nutrients, temperature, soil reaction, plant species, and light for vascular plants [40]. These values were used for the assessment of the plant responses derived from the phytosociological relevés, using van der Maarel's indices instead of the abundance-dominance coefficient to minimize the weight of the dominant species. We also studied the effect of the number of nests, plant species richness, and bare ground spots without vegetation on the assemblages of predators.

Spiders, harvestmen, and centipedes were collected by pitfall traps (using five formaldehyde traps at each plot, $20 \mathrm{~m}$ spacing, pooled material from all five traps was a sample) and were inspected in two-week intervals from May to November of 2012, 2013, and 2014 respectively. Spiders, harvestmen, and centipedes were identified to the species level [41-44], with some juveniles to the genus or family level only. The actual nomenclature followed the World Spider Catalogue Version 21.5 [45], World Catalogue of Opiliones [46], and ChiloBase 2.0 [47], respectively. All material was deposited in author's collections. Hunting strategies guild of spiders followed Cardoso et al. [37].

\section{Statistical Analyses}

The data set consisted of 144 samples, of which 133 individual groups were obtained. For each of them, the total activity-density and species richness of invertebrates were calculated, including the activity-density of individual species (response variables). Environmental factors (explanatory variables) were data of coverage (density of tree, shrub and herbal layers, and bare ground), Ellenberg indicator values (Shannon's diversity index, light, temperature, humidity, soil reactions, nutrition, and plant species), and number of cormorant nests. The analyses were performed with R [48] and Canoco 5 [49]. The effect of explanatory variables on activity-density and species richness was analysed using generalized linear models (GLM) in the R program. Due to over-dispersion in the data (variance was higher than mean), a negative binomial distribution was used, and the model was fitted with a log link [50].

We used a constrained ordination method for the data analysis, followed by canonical correspondence analysis (CCA) in the Canoco 5, which was recommended based on the data distribution. A log transformation was used for the response variables (species), and unrestricted permutations with 499 permutations were set. In several modifications, 
we evaluated the relationship between explanatory and response variables. In the first variant, all explanatory variables entered the model and their simple and conditional effect (summarized effects of explanatory variables) on individual species was determined. In the second variant, in the same way, we tested just using the explanatory variables in our calculations, which were proven to be significant in the GLM analysis (bare ground, herbal layer, plant species, light, and nests). Subsequently, we limited this analysis only to species whose total activity-density was higher than 20 individuals (for clarity of graphic outputs). In addition, for species with an activity-density greater than 20, their response curves to selected explanatory variables were processed. Only coverage variables were included among them, due to their potentially direct effect on invertebrates. Generalized additive models (GAM) were used for the analysis, which enabled a more detailed fitting of the response of individual species. For the model options, a Poisson distribution with a quasi distribution approach was chosen, due to over-dispersion in the response variable.

\section{Results}

We collected 4299 specimens of spiders, representing 102 identified species from 18 families; 451 specimens of harvestmen, representing 9 identified species from 3 families; and 1501 specimens of centipedes, representing 7 identified species from 4 families (Table 1). Some specimens of spiders were identified only to the genus or family level. Of these, 36 species were classified as preferring forest habitats, 34 preferring open habitats, and 48 were eurytopic species (Table S1, Supplementary Materials). The most diverse families for spiders, harvestmen, and centipedes were Linyphiidae (39 species), Phalangiidae (6), and Lithobiidae (5), respectively. The most frequent spider species were Trochosa terricola Thorell, 1856 (39\% from all spider material), Diplostyla concolor (Wider, 1834) (14\%), and Pachygnatha listeri Sundevall, 1830 (5\%); harvestmen were Phalangium opilio Linnaeus, 1761 (40\%) and Nemastoma lugubre (Müller, 1776) (23\%); and centipede was Lithobius forficatus (L.) (86\%). In comparison with the control plot (D), the presence of a cormorant colony had a negative effect to opiliones (lowest number on the starting colony, and the highest on the unaffected control). On the other hand, spiders and centipedes were affected positively-the lowest abundance were on control site (D) and the highest in the starting colony (A, spiders) and active colony (B, centipedes) (Table 1$)$. The number of species was similar on all of the plots (A: Araneae-65, Opiliones-4, Chilopoda-7; B: Araneae-68, Opiliones-7, Chilopoda-5; C: Araneae-68, Opiliones-7, Chilopoda-5, D: Araneae-35, Opiliones-6, Chilopoda-5).

Table 1. Summary of obtained epigeic groups of predators. A—starting colony; B—dense active colony; C-abandoned colony; D—control pine forest without cormorants; G/S/I—number of genera, species and individuals; +_ “at least" due to juveniles identified to genus or family level only.

\begin{tabular}{|c|c|c|c|c|c|}
\hline & A & B & $\mathrm{C}$ & D & Together \\
\hline Order/Family & $\mathrm{G} / \mathrm{S} / \mathrm{I}$ & $\mathrm{G} / \mathrm{S} / \mathrm{I}$ & $\mathrm{G} / \mathrm{S} / \mathrm{I}$ & $\mathrm{G} / \mathrm{S} / \mathrm{I}$ & $\mathrm{G} / \mathrm{S} / \mathrm{I}$ \\
\hline \multicolumn{6}{|c|}{ Araneae (Spiders) } \\
\hline Agelenidae & $0 / 0 / 0$ & $1 / 1 / 1$ & $1 / 1 / 20$ & $0 / 0 / 0$ & $1 / 1 / 21$ \\
\hline Clubionidae & $1 / 2+/ 4$ & $1 / 2 / 2$ & $1 / 2+/ 38$ & $1 / 2+/ 5$ & $1 / 6+/ 49$ \\
\hline Dyctinidae & $0 / 0 / 0$ & $1 / 1 / 1$ & $0 / 0 / 0$ & $0 / 0 / 0$ & $1 / 1 / 1$ \\
\hline Gnaphosidae & $5 / 6+/ 10$ & $4 / 8 / 16$ & $6 / 10+/ 180$ & $0 / 0 / 0$ & $6 / 10+/ 206$ \\
\hline Hahniidae & $0 / 0 / 0$ & $2 / 3 / 3$ & $0 / 0 / 0$ & $0 / 0 / 0$ & $2 / 3 / 3$ \\
\hline Linyphiidae & $18+/ 22+/ 233$ & $18+/ 22+/ 232$ & $15 / 22 / 212$ & $13+/ 19+/ 383$ & $26+/ 39+/ 1050$ \\
\hline Liocranidae & $1 / 1 / 7$ & $0 / 0 / 0$ & $1 / 1 / 1$ & $0 / 0 / 0$ & $1 / 1 / 8$ \\
\hline Lycosidae & $4 / 7+/ 950$ & $3 / 6+/ 708$ & $4 / 8+/ 453$ & $2 / 3+/ 209$ & $4 / 10+/ 2320$ \\
\hline Mimetidae & $1 / 1 / 1$ & $1 / 1 / 1$ & $0 / 0 / 0$ & $0 / 0 / 0$ & $1 / 1 / 2$ \\
\hline Miturgidae & $0 / 0 / 0$ & $1 / 1 / 3$ & $1 / 1 / 4$ & $1 / 1 / 1$ & $1 / 1 / 8$ \\
\hline
\end{tabular}


Table 1. Cont.

\begin{tabular}{|c|c|c|c|c|c|}
\hline & A & B & $\mathrm{C}$ & $\mathbf{D}$ & Together \\
\hline Order/Family & G/S/I & G/S/I & G/S/I & G/S/I & G/S/I \\
\hline Philodromidae & $1 / 2+/ 12$ & $1 / 4+/ 20$ & $1 / 1 / 1$ & $1 / 1 / 1$ & $2 / 6+/ 40$ \\
\hline Phrurolithidae & $1 / 1 / 1$ & $1 / 1 / 1$ & $1 / 1 / 1$ & $0 / 0 / 0$ & $1 / 1 / 3$ \\
\hline Pisauridae & $0 / 0 / 0$ & $0 / 0 / 0$ & $1 / 1 / 3$ & $0 / 0 / 0$ & $1 / 1 / 3$ \\
\hline Salticidae & $3 / 3 / 8$ & $3 / 3 / 5$ & $1 / 1 / 4$ & $0 / 0 / 0$ & $4 / 4 / 17$ \\
\hline Segestridae & $1 / 1 / 3$ & $0 / 0 / 0$ & $1 / 1 / 1$ & $1 / 1 / 1$ & $1 / 1 / 5$ \\
\hline Tetragnathidae & $3 / 5+/ 124$ & $3 / 4+/ 156$ & $2 / 5+/ 48$ & $2 / 2+/ 14$ & $3 / 6+/ 342$ \\
\hline Theridiidae & $3 / 3 / 8$ & $3 / 3 / 6$ & $5 / 6 / 13$ & $1 / 1 / 2$ & $6 / 7 / 29$ \\
\hline Thomisidae & $2 / 3+/ 73$ & $1 / 2+/ 48$ & $1 / 1+/ 25$ & $1 / 2+/ 46$ & $2 / 3+/ 192$ \\
\hline \multicolumn{6}{|c|}{ Opiliones (harvestmen) } \\
\hline Nemastomatidae & $1 / 1 / 4$ & $1 / 1 / 5$ & $2 / 2 / 36$ & $1 / 1 / 62$ & $2 / 2 / 107$ \\
\hline Phalangiidae & $2 / 2 / 64$ & $4 / 5 / 88$ & $3 / 3 / 46$ & $5 / 5 / 104$ & $5 / 6 / 302$ \\
\hline Sclerosomatidae & $1 / 1 / 3$ & $1 / 1 / 7$ & $1 / 1 / 32$ & $0 / 0 / 0$ & $1 / 1 / 42$ \\
\hline \multicolumn{6}{|c|}{ Chilopoda (centipedes) } \\
\hline Lithobiidae & $1 / 5 / 437$ & $1 / 4 / 498$ & $1 / 4 / 325$ & $1 / 4 / 204$ & $1 / 5 / 1464$ \\
\hline Geophilidae & $1 / 1 / 1$ & $0 / 0 / 0$ & $0 / 0 / 0$ & $0 / 0 / 0$ & $1 / 1 / 1$ \\
\hline Linotaeniidae & $1 / 1 / 14$ & $1 / 1 / 8$ & $1 / 1 / 11$ & $1 / 1 / 3$ & $1 / 1 / 36$ \\
\hline
\end{tabular}

Significant effects on the abundance and species diversity of spiders, harvestmen, and centipedes were factors of bare ground, nest density, Ellenberg indicator values for light, herb layer coverage, and number of plant species (Table 2). Abundance of epigeic predators increased with nest density, bare soil, and Ellenberg indicator values for light, and decreased with herb and moss coverage (Figure 1). Species diversity increased with nest density and bare soil, and decreased with Ellenberg indicator values for light and herb coverage (Figure 1). Tree and shrub layer coverage did not have a significant effect on species diversity and the abundances of epigeic predators, as well as Ellenberg indicator values for humidity, soil reactions, nutrition, and plant species.

Table 2. Summary of fitted generalized additive models for species with an activity-density greater than 20, and their numerical response to coverage variables. Bare ground-patches without vegetation; herbal layer-coverage (\%) of ground by herbs; plant species-number of plant species; nests-mean number of cormorant nests per $100 \mathrm{~m}^{2}$.

\begin{tabular}{lcccccccccccc}
\hline & \multicolumn{3}{c}{ Bare Ground } & \multicolumn{3}{c}{ Herbal Layer } & \multicolumn{3}{c}{ Plant Species } & \multicolumn{2}{c}{ Nests } \\
\cline { 2 - 12 } & $\mathbf{R 2}$ & $\mathbf{F}$ & $\boldsymbol{p}$ & $\mathbf{R 2}$ & $\mathbf{F}$ & $\boldsymbol{p}$ & $\mathbf{R 2}$ & $\mathbf{F}$ & $\boldsymbol{p}$ & $\mathbf{R 2}$ & $\mathbf{F}$ & $\boldsymbol{p}$ \\
\hline Agelena labyrinthica & 39.1 & 17.4 & $<0.01$ & 38.3 & 16.7 & $<0.01$ & 24.2 & 5.2 & $<0.01$ & 21.3 & 4.1 & $<0.05$ \\
Centromerus serratus & 7.4 & 1.4 & n.s. & 17.9 & 2.9 & $<0.10$ & 10.7 & 1.6 & n.s. & 22.1 & 7.3 & $<0.01$ \\
Centromerus sylvaticus & 4.8 & 1.1 & n.s. & 5.1 & 1.2 & n.s. & 6.9 & 1.7 & n.s. & 1.0 & 0.2 & n.s. \\
Ceratinella brevis & 8.6 & 2.6 & $<0.10$ & 3.8 & 0.9 & n.s. & 14.4 & 4.7 & $<0.05$ & 10.7 & 3.0 & $<0.10$ \\
Dicymbium tibiale & 14.2 & 3.3 & 0.042 & 12.1 & 3.1 & $<0.10$ & 8.9 & 1.9 & n.s. & 23.2 & 5.5 & $<0.01$ \\
Diplostyla concolor & 10.6 & 5.7 & $<0.01$ & 16.8 & 10.0 & $<0.01$ & 15.6 & 8.9 & $<0.01$ & 13.4 & 7.3 & $<0.01$ \\
Ozyptila praticola & 5.2 & 1.8 & n.s. & 4.7 & 1.6 & n.s. & 5.2 & 1.8 & n.s. & 1.4 & 0.4 & n.s. \\
Ozyptila trux & 28.3 & 10.2 & $<0.01$ & 22.5 & 7.7 & $<0.01$ & 19.9 & 6.0 & $<0.01$ & 20.4 & 6.1 & $<0.01$ \\
Pachygnatha degeeri & 19.4 & 6.0 & $<0.01$ & 17.4 & 4.6 & $<0.05$ & 9.7 & 2.0 & n.s. & 19.6 & 6.0 & $<0.01$ \\
Pachygnatha listeri & 25.8 & 16.8 & $<0.01$ & 22.7 & 13.8 & $<0.01$ & 26.9 & 16.4 & $<0.01$ & 20.0 & 11.5 & $<0.01$ \\
Pardosa agrestis & 22.0 & 5.9 & $<0.01$ & 21.2 & 5.5 & $<0.01$ & 29.6 & 9.6 & $<0.01$ & 33.8 & 14.6 & $<0.01$ \\
Pardosa lugubris & 33.0 & 17.6 & $<0.01$ & 25.9 & 11.5 & $<0.01$ & 26.5 & 12.4 & $<0.01$ & 24.8 & 11.1 & $<0.01$ \\
Pardosa prativaga & 1.3 & 0.3 & n.s. & 3.1 & 0.7 & n.s. & 8.5 & 2.3 & n.s. & 12.8 & 3.0 & $<0.10$ \\
Pardosa saltans & 10.7 & 3.4 & $<0.05$ & 11.2 & 3.4 & $<0.05$ & 20.1 & 9.7 & $<0.01$ & 12.0 & 4.0 & $<0.05$ \\
\hline
\end{tabular}


Table 2. Cont.

\begin{tabular}{lcccccccccccc}
\hline & \multicolumn{3}{c}{ Bare Ground } & \multicolumn{3}{c}{ Herbal Layer } & \multicolumn{3}{c}{ Plant Species } & \multicolumn{3}{c}{ Nests } \\
\cline { 2 - 12 } & $\mathbf{R 2}$ & $\mathbf{F}$ & $\mathbf{p}$ & $\mathbf{R 2}$ & $\mathbf{F}$ & $\boldsymbol{p}$ & $\mathbf{R 2}$ & $\mathbf{F}$ & $\boldsymbol{p}$ & $\mathbf{R 2}$ & $\mathbf{F}$ & $\boldsymbol{p}$ \\
\hline Pardosa sp. & 12.0 & 2.7 & $<0.10$ & 11.5 & 2.5 & $<0.10$ & 22.6 & 7.6 & $<0.01$ & 18.9 & 5.7 & $<0.01$ \\
Tenuiphantes flavipes & 13.9 & 5.1 & $<0.01$ & 11.0 & 3.8 & $<0.05$ & 10.9 & 3.6 & $<0.05$ & 10.6 & 3.9 & $<0.05$ \\
Trochosa terricola & 15.2 & 7.9 & $<0.01$ & 11.9 & 5.8 & $<0.01$ & 11.2 & 5.0 & $<0.01$ & 10.7 & 5.0 & $<0.01$ \\
Trochosa sp. & 3.2 & 1.5 & n.s. & 2.3 & 1.0 & n.s. & 7.0 & 3.4 & $<0.05$ & 4.7 & 2.2 & n.s. \\
Zelotes subteraneus & 26.9 & 15.9 & $<0.01$ & 31.4 & 21.2 & $<0.01$ & 35.6 & 28.4 & $<0.01$ & 42.3 & 36.1 & $<0.01$ \\
Zelotes sp. & 17.4 & 4.6 & $<0.05$ & 22.2 & 6.8 & $<0.01$ & 23.3 & 7.9 & $<0.01$ & 20.9 & 5.8 & $<0.01$ \\
\hline Leiobunum rotundum & 29.4 & 12.0 & $<0.01$ & 31.4 & 13.9 & $<0.01$ & 11.5 & 2.3 & n.s. & 11.3 & 2.3 & n.s. \\
Oligolophus tridens & 5.1 & 1.1 & n.s. & 20.9 & 5.4 & $<0.01$ & 18.8 & 3.8 & $<0.05$ & 13.3 & 3.3 & $<0.05$ \\
Mitopus morio & 4.0 & 0.7 & n.s. & 3.8 & 0.7 & n.s. & 2.3 & 0.4 & n.s. & 9.8 & 2.0 & n.s. \\
Nemastoma lugubre & 21.6 & 11.2 & $<0.01$ & 20.6 & 11.0 & $<0.01$ & 18.8 & 9.9 & $<0.01$ & 23.1 & 13.1 & $<0.01$ \\
Phalangio opilio & 3.3 & 1.2 & n.s. & 3.9 & 1.4 & n.s. & 5.5 & 2.1 & n.s. & 3.0 & 1.0 & n.s. \\
\hline Lithobius forficatus & 29.1 & 23.2 & $<0.01$ & 29.4 & 23.8 & $<0.01$ & 24.3 & 18.8 & $<0.01$ & 31.3 & 26.2 & $<0.01$ \\
Lithobius & 11.1 & 6.8 & $<0.01$ & 17.1 & 11.6 & $<0.01$ & 25.7 & 20.7 & $<0.01$ & 24.8 & 20.0 & $<0.01$ \\
erythrocephalus & 14.7 & 6.9 & $<0.01$ & 16.6 & 7.9 & $<0.01$ & 32.1 & 18.1 & $<0.01$ & 34.4 & 21.8 & $<0.01$ \\
Lithobius microps & 6.7 & 2.9 & $<0.10$ & 5.6 & 2.4 & $<0.10$ & 1.7 & 0.7 & n.s. & 5.9 & 2.6 & $<0.10$ \\
Lithobius curtipes & 4.0 & 2.0 & n.s. & 1.9 & 0.9 & n.s. & 5.5 & 2.9 & $<0.10$ & 5.1 & 2.6 & $<0.10$ \\
Strigamia acuminata & 4.0 & & & & & & & & & &
\end{tabular}

Nest density, bare ground, Ellenberg indicator values for light, herb layer cover, and number of plant species affected the ecological diversity of ground dwelling predators (habitat preferences, stratum, and hunter guilds) (Figure 2). Species preferring open habitats and eurytopic species dominated on lighter plots with bare ground and high nest density. No clear affinity of and group of predators was evident for guild according to the preferred stratum or hunting strategy (Figure 2).

Nest density, number of plant species, herbal layer, and bare ground cover had a significant effect on the activity-density of some species of ground dwelling predatory arthropods. Tree and shrub layer coverage did not significantly influence the activitydensity of the model taxa. The activity-density of 17 species was significantly affected by the presence of bare ground and herb layer coverage (Figure 3 and Table 2), and the activity of 18 species was affected by nest density and number of plant species (Figure 3 and Table 2). 

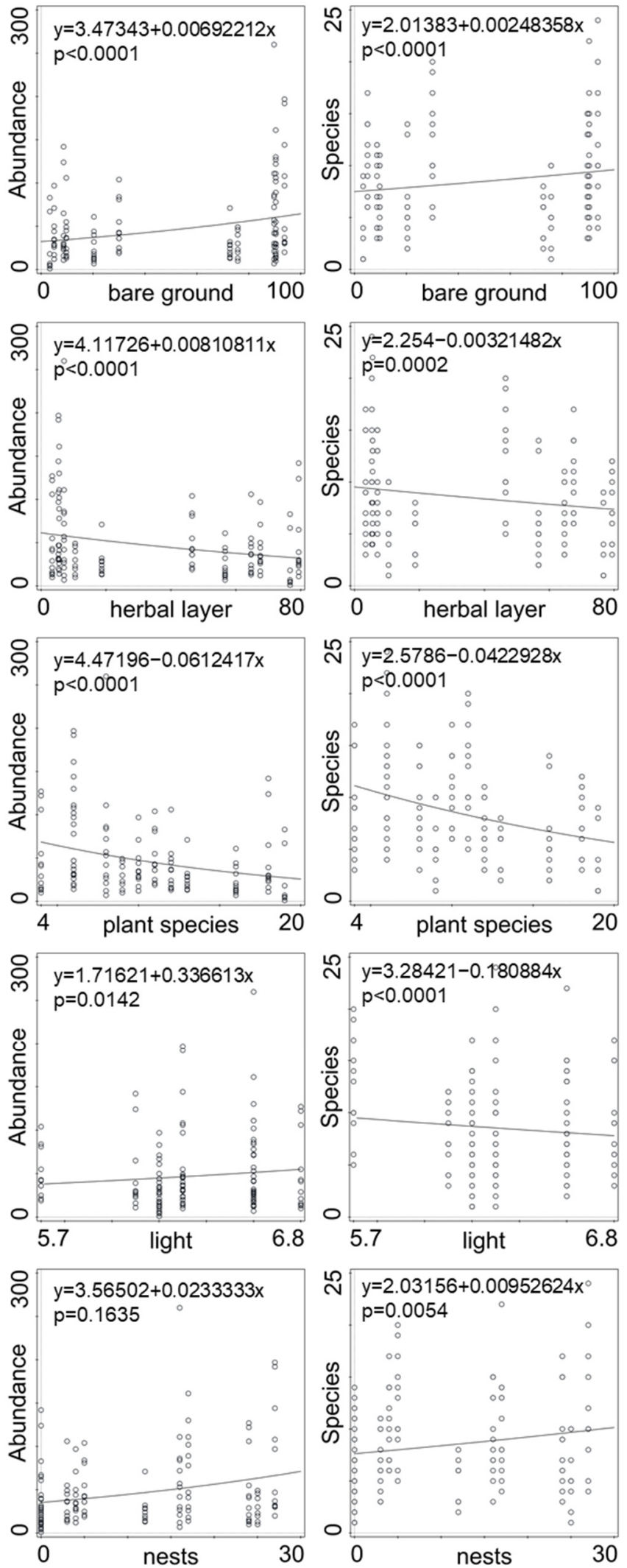

Figure 1. Significant factors and their effect on the abundance and number of species (GLM). Bare ground-percentage of patches without vegetation; herbal layer-coverage (\%) of ground by herbs; plant species—number of plant species; light—value of Ellenberg index for light; nests-mean number of cormorant nests per $100 \mathrm{~m}^{2}$. R2 for whole minimal adequate model for abundance of predatory arthropods is 0.792 and 0.689 for number of species, respectively. 


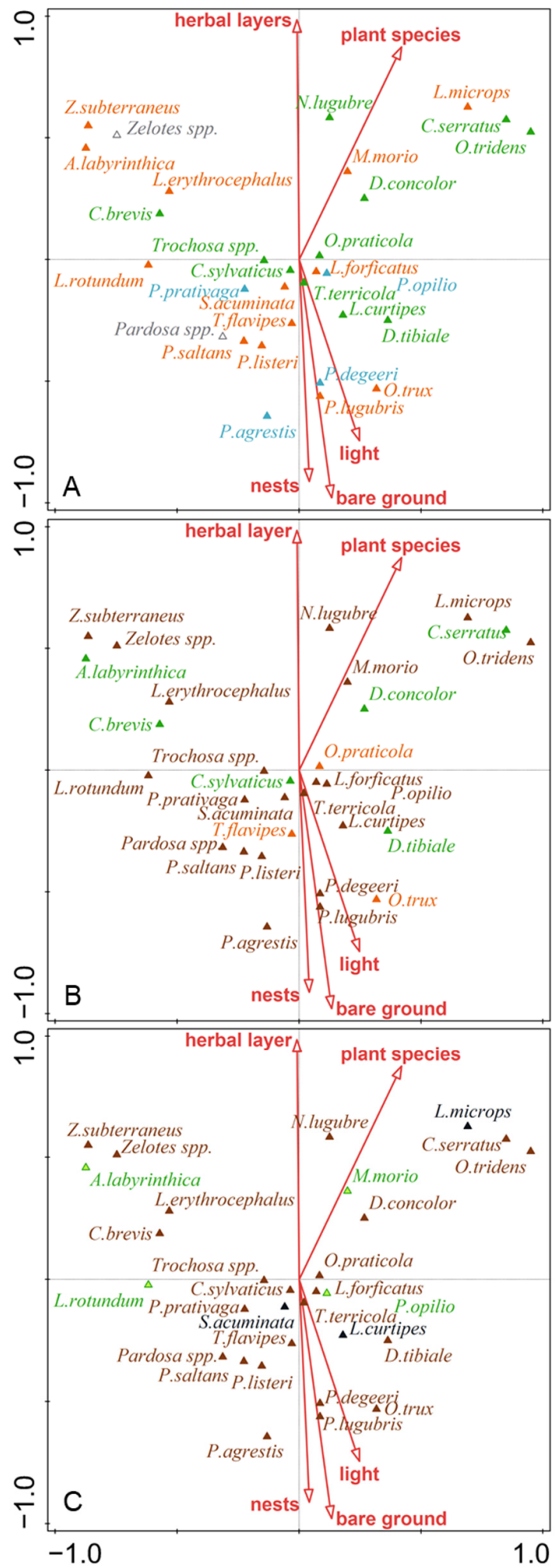

Figure 2. CCA biplots of selected groups of predatory arthropod distribution in cormorant colonies with significant factors predicting their activity-density: (A) guilds according to habitat preference (green—forest species; orange—eurytopic species; blue—non-forest species); (B) guilds according to hunter strategy guilds (green-sheet web hunters; orange-ambush hunters; brown-ground hunters); (C) preferred stratum guilds (brown-epigeic species; green-herb species; black—soil living species). Bare ground-patches without vegetation; herbal layer-coverage (\%) of ground by herbs; plant species_-number of plant species; light-Ellenberg indicator values for light; nestsmean number of cormorant nests per $100 \mathrm{~m}^{2}$. 

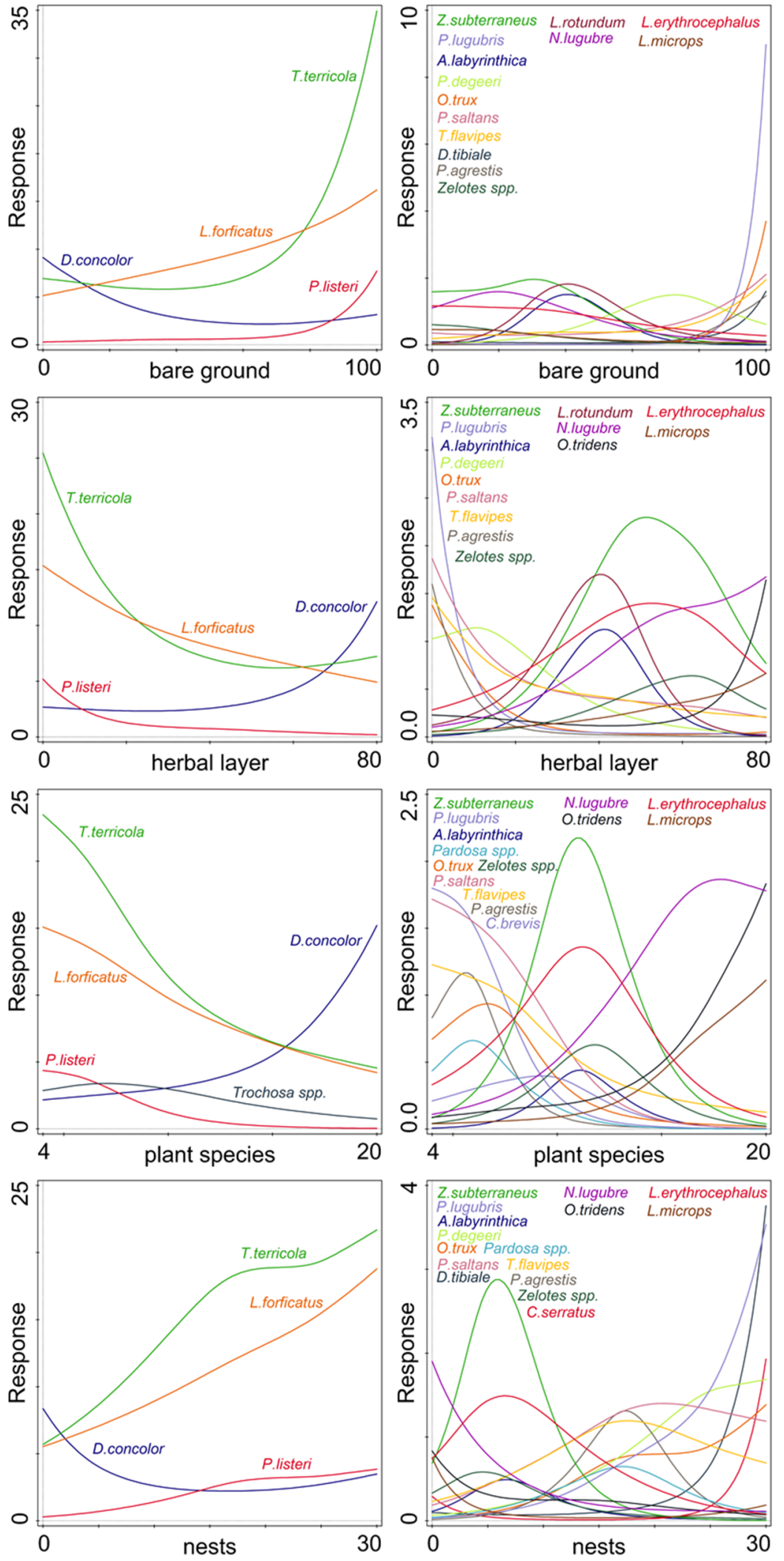

Figure 3. Effect of significant factors on the activity-density of species with a significant response (see Table 2). Left column-numerous species (>50 specimens); right column-less numerous species (20-50 specimens); bare ground-percentages of patches without vegetation; herbal layer-coverage (\%) of ground by herbs; plant species-number of plant species; nests-mean number of cormorant nests per $100 \mathrm{~m}^{2}$. 


\section{Discussion}

We analysed how vegetation structure affected by a cormorant colony influenced the activity-density and species richness of spiders, harvestmen, and centipedes in the Curonian Spit National Park in Lithuania. We obtained a total of 102 identified species of spiders in all plots of the cormorant colony, that is, about half of known spider species in the Curonian Spit (Machač, unpubl. data) and about quarter of know species in Lithuania [24]. Only one-third of the species were typical forest species, the remaining species were open habitat dwellers or eurytopic species without habitat preference [44]. The obtained harvestmen were classified as forest species, and only P. opilio and Rilaena triangularis (Herbst, 1799) are open habitat dwellers [51]. The relatively high proportion of non-forest species may have been caused by vegetation changes in dying forests, thus creating a habitat mosaic with different plant coverage from bare ground without vegetation to densely covered patches of nitrophilous species $[4,18]$. Grey heron colonies have a similar effect on their ecosystems $[6,7,52]$, which was similar to the studied cormorant colony. The common European forest spiders were the dominant species with the highest activity-density, as well as open habitats-dweller harvestmen P. opilio, and forest species N. lugubre [51] and eurytopic centipedes L. forficatus [26].

Bare ground, Ellenberg indicator values for light, and density of cormorant nests significantly positively influenced the activity-density of ground dwelling predatory arthropods in the colony. In the plots with a high density of nests were a higher density of exposed bare ground, and more light patches without vegetation or only sparse vegetation with many prey remains (mussels and fish scales) and faeces [18]. Such patches attract predators, scavengers, and coprophagous species [12], but not spiders and centipedes [53]. A higher abundance of predators in dense bird colonies, as explained by Polis and Hurd [54], demonstrated an extraordinary abundance of its prey-scavengers and parasites. This extraordinary food offer is more attractive for centipedes than dead wood lying in the abandoned colony, although the dead wood is usually a strong attractant for them [55]. On the other hand, higher abundances of web-build spiders and lycosid spiders in cormorant colonies in Sweden were more typical in abandoned colonies than the active ones [14], although in both types of colonies, the spiders decreased in abundance with distance from the cormorant nests. Similarly to in our study, the abundance of spiders in the starting colony was higher than in the active one. A similar pattern was found for spiders in the cormorant colonies in Socotra [21].

Surprisingly, tree and shrub coverage did not have a significant effect on the abundance and species structure of predators, although tree coverage and canopy openness are known have an impact on spider densities [29,31]. On the other site, herb layer coverage and plant diversity had negative effect on abundance and species richness of predators. Craig et al. [12] show, on such sites, herbivore arthropods are more abundant and diverse than in active bird colonies.

The effect of some factors (Ellenberg indicator value for light, nests, bare ground, herbal layer, and plant species) on ecological species diversity guilds was significant, but no distinct effect on species according to their biology was evident. The effect of the Ellenberg indicator value for light on the abundance of predators was reported by Lafage et al. [27] in oligotrophic habitats in France. The structure of vegetation and microhabitat mosaic rather than age of habitat has repeatedly been shown to determine the species richness of spiders [30].

Some environmental factors showed a significant effect of the activity-density of some predatory species. Bare ground patches were attractive for T. terricola, L. forficatus, and $P$. listeri. All these species are cursorial hunters actively searching for their prey. Such invertebrate prey are dense on bird excrements and prey remains $[14,17]$.

Similar to our results, Uetz [29] found that an abundance of spiders from the family Lycosidae (as Trochosa and Pardosa species) was negatively influenced by increasing the litter depth and vegetation coverage of the herbal layer. Changes in vegetation coverage and structural conditions of leaf litter affected the mobility of individuals of cursorial 
hunters. On the other hand, low mobile predators, such as sheet web spider D. concolor or harvestmen $N$. lugubre, had the opposite response. These species prefer a moist dense herbal layer $[51,56]$.

Cormorants had a negative impact on forests, but formed mosaics of different habitats (patches with different succession stages and vegetation structure). For some species and groups of spiders, harvestmen, and centipedes, such plots are attractive. This is the first study evaluating the effect of a cormorant colony on ground dwelling arthropods, including time patterns.

\section{Conclusions}

Great cormorants are avian fish predators, whose populations have recently been rising throughout Europe. We studied assemblages of spiders, harvestmen, and centipedes in different influenced plots in the biggest cormorant colony in Lithuania and the birds' resulting influence of changes in vegetation on the abundance and diversity of arthropods. Cormorants had a negative impact on the forest, but formed mosaics of different habitats (patches with different succession stages and vegetation structure). For some species and groups of spiders, harvestmen, and centipedes, such plots are attractive. This is the first study evaluating the effect of a cormorant colony on ground dwelling arthropods, including time patterns. Although we studied only one cormorant colony, the strong suit of this study is the documentation of the real process of succession and changes of arthropod communities following changes of environmental variables. From this reason, our case study presents valuable data about the effect of cormorant colonies on ground dwelling predatory arthropods in this region.

Supplementary Materials: The following supporting information can be downloaded at: https: / / www.mdpi.com/article/10.3390/f13020330/s1. Table S1: Species list with characteristic and numbers of trapped individuals.

Author Contributions: Conceptualization, P.I. and J.R.; methodology, P.I. and J.R.; validation, O.M. and I.H.T.; formal analysis, O.H. and I.H.T.; investigation, O.M., P.I., J.R. and I.H.T.; resources, O.M.; data curation, O.M. and I.H.T.; writing—original draft preparation, O.M., P.I., J.R., O.H. and I.H.T.; writing - review and editing, O.M., O.H. and I.H.T.; visualization, O.M., O.H. and I.H.T.; supervision, I.H.T. All authors have read and agreed to the published version of the manuscript.

Funding: This research was funded by the Research Council of Lithuania (no. LEK-03/2012) and partly by the internal grant of the Faculty of Science of Palacký University Olomouc (IGA_PrF_2021_014).

Data Availability Statement: The data presented in this study are openly available in FigShare at https:/ / doi.org/10.6084/m9.figshare.19184687.v1.

Acknowledgments: We are grateful to Dalytè Matulevičiūtè and her colleagues for their botanical data of coverage on study plots, and to head of the scientific project, Jurga Motiejūnaite, for the organizing and inspiration of the work. We wish to thank the specialist of Curonian Spit National Park for help during the work. We also thank Michal Hroneš (Department of Botany, Palacký University Olomouc) for help with analyse Ellenberg indicator values of vascular plants. This study was funded by a grant (no. LEK-03/2012) from the Research Council of Lithuania. We are grateful to Ben Rhodes who kindly edited an advanced draft for English usage, and to two anonymous reviewers for their valuable comments and suggestions.

Conflicts of Interest: The authors declare no conflict of interest.

\section{References}

1. Del Hoyo, J.; Elliott, P.; Sargatal, J. Ostrich to Ducks. In Handbook of the Birds of the World; Lynx Edicions: Barcelona, Spain, 1992.

2. Van Eerden, M.R.; van Rijn, S.; Volponi, S.; Paquet, J.Y.; Carss, D. Cormorant and the European Environment: Exploring Cormorant Ecology on a Continental Scale; NERC/Centre for Ecology \& Hydrology: Lancaster, UK, 2012.

3. Herrmann, C.; Bregnballe, T.; Larsson, K.; Leivits, M.; Rusanen, P. Population Development of Baltic Bird Species: Great Cormorant (Phalacrocorax carbo sinensis); HELCOM: Helsinki, Finland, 2018.

4. Klimaszyk, P.; Rzymski, P. The complexity of ecological impacts induced by great cormorants. Hydrobiologia 2016, 771, 13-30. [CrossRef] 
5. Bzoma, S. Protection of Cormorant Phalacrocorax carbo in Poland-Project Strategy of Management of Cormorant Population in Poland; Warsaw University of Life Sciences: Warsaw, Poland, 2011.

6. Hryń, W.; Czarnecka, J.; Kitowski, I.; Bartmiński, P.; Zubel, R. Stress or help, how does the grey heron Ardea cinerea L. modify the vegetation structure of the forest floor? Acta Soc. Bot. Pol. 2019, 88, 3625. [CrossRef]

7. Hryń, W.; Czarnecka, J.; Kitowski, I.; Franczak, M.; Bartmiński, P. How does the engineering species affect forest ecosystems? Changes in germination and development rate of non-forest species under the nests of Ardea cinerea L. Ekológia 2020, 39, 250-259. [CrossRef]

8. Klimaszyk, P.; Brzeg, A. Long-term changes in the ecosystem of a lake (Lake Strzyżminskie) and an island induced by a colony of Great Cormorants (Phalacrocorax carbo sinensis L.). Oceanol. Hydrobiol. Stud. 2015, 44, 316-325. [CrossRef]

9. Goc, M.; Iliszko, L.; Stempniewicz, L. The largest European colony of great cormorant on the Vistula spit (N. Poland) an impact of the forest ecosystem. Ecol. Quest. 2005, 6, 93-103.

10. Britto, D.T.; Kronzucker, H.J. NH ${ }^{4+}$ toxicity in higher plants: A critical review. J. Plant Physiol. 2012, 159, 567-584. [CrossRef]

11. Lafferty, D.J.; Hanson-Dorr, K.C.; Prisock, A.M.; Dorr, B.S. Biotic and abiotic impacts of Double-crested Cormorant breeding colonies on forested islands in the southeastern United States. For. Ecol. Manag. 2016, 369, 10-19. [CrossRef]

12. Craig, E.C.; Elbin, S.B.; Danoff-Burg, J.A.; Palmer, M.I. Impacts of double crested cormorants (Phalacrocorax auritus) and other colonial waterbirds on plant and arthropod communities on islands in an urban estuary. Waterbirds 2012, 35, 4-12. [CrossRef]

13. Boutin, C.; Dobbie, T.; Carpenter, D.; Hebert, C.E. Effect of Double Crested Cormorant on island vegetation, seedbank and soil chemistry: Evaluating island restoration potential. Restor. Ecol. 2011, 19, 720-727. [CrossRef]

14. Kolb, G.S.; Jerling, L.; Essenberg, C.; Palmborg, C.; Hambäck, P.A. The impact of nesting cormorants on plant and arthropod diversity. Ecography 2012, 35, 726-740. [CrossRef]

15. Veum, L.M.; Dorr, B.S.; Hanson-Dorr, K.C.; Moore, R.J.; Rush, S.A. Double-crested cormorant colony effects on soil chemistry, vegetation structure and avian diversity. For. Ecol. Manag. 2019, 453, 11. [CrossRef]

16. Ivinskis, P.; Rimšaite, J. Distribution and abundance of Geotrupidae in different habitats of Curonian Spit. Acta Biol. Univ. Daugavp. 2013, 13, 37-43.

17. Yahiro, K.; Kameda, K.; Nasu, Y.; Murahama, S. Insect fauna of great cormorant (Phalacrocorax carbo) nests. Jpn. J. Ent. 2013, 16, 15-23.

18. Matulevičiūtè, D.; Motiejūnaitè, J.; Uogintas, D.; Taraškevičius, R.; Dagys, M.; Rašomavičius, V. Decline of a protected coastal pine forest under impact of a colony of great cormorants and the rate of vegetation change under ornithogenic influence. Silva Fenn. 2018, 52, 7699. [CrossRef]

19. Balčiauskas, L.; Skipityte, R.; Jasiulionis, M.; Balčiauskiene, L.; Remeikis, V. Immediate increase in isotopic enrichment in small mammals following the expansion of great cormorant colony. Biogeosciences 2018, 15, 3883. [CrossRef]

20. Balčiauskienè, L.; Jasiulionis, M.; Balčiauskas, L. Loss of diversity in a small mammal community in a habitat influenced by a colony of great cormorants. Acta Zool. Bulg. 2014, 66, 229-234.

21. Al Shehhi, H.; Muzaffar, S.B. Impact of nesting Socotra Cormorants on terrestrial invertebrate communities. Insects 2021, $12,615$. [CrossRef]

22. Osono, T.; Hobara, S.; Koba, K.; Kameda, K.; Takeda, H. Immobilization of avian excretaderived nutrients and reduced lignin decomposition in needle and twig litter in a temperate coniferous forest. Soil Biol. Biochem. 2016, 38, 517-525. [CrossRef]

23. Žydelis, R.; Gražulevičius, G.; Zarankaitè, J.; Mečionis, R.; Mačiulis, M. Expansion of the Cormorant (Phalacrocorax carbo sinensis) population in western Lithuania. Acta Zool. Litu. 2002, 12, 283-287. [CrossRef]

24. Biteniekytè, M.; Rèlys, V. The checklist of Lithuanian spiders (Arachnida: Araneae). Biologija 2011, 57, 148-158. [CrossRef]

25. Machač, O.; Ivinskis, P.; Rimšaitè, J. Several new for Lithuanian fauna species of spiders (Araneae). Neww Rare Lith. Insect Species 2016, 28, 121-126

26. Tuf, I.H.; Ivinskis, P.; Rimšaite, J. A check-list of the centipedes (Chilopoda) of Lithuania. Zootaxa 2015, 4052, 394-400. [CrossRef] [PubMed]

27. Lafage, D.; Djoudi, E.A.; Perrin, G.; Gallet, S.; Pétillon, J. Responses of ground-dwelling spider assemblages to changes in vegetation from wet oligotrophic habitats of Western France. Arthropod-Plant Interact. 2019, 13, 653-662. [CrossRef]

28. Duffy, E. Ecological strategies in spiders including some characteristics of species in pioneer and mature habitats. Symp. Zool. Soc. Lond. 1978, 42, 83-107.

29. Uetz, G.W. Influence of variation of litter habitats on spider communities. Oecologia 1979, 40, 29-42. [CrossRef] [PubMed]

30. Hurd, L.E.; Fagan, W.F. Cursorial spiders and succession: Age of habitat structure? Oecologia 1992, 92, 215-221. [CrossRef]

31. Košulič, O.; Michalko, R.; Hula, V. Impact of canopy openness on spider communities: Implications for conservation management of formerly coppiced oak forests. PLoS ONE 2016, 11, e0148585. [CrossRef]

32. Ávila, A.C.; Stenert, C.; Rodrigues, E.N.L.; Maltchik, L. Habitat structure determines spider diversity in highland ponds. Ecol. Res. 2017, 32, 359-367. [CrossRef]

33. Wise, D.H. Spiders in Ecological Webs; Cambridge University Press: Cambridge, UK, 1993. [CrossRef]

34. Entling, W.; Schmidt, M.H.; Bacher, S.; Brandl, R.; Nentwig, W. Niche properties of Central European spiders: Shading, moisture and the evolution of the habitat niche. Glob. Ecol. Biogeogr. 2007, 16, 440-448. [CrossRef]

35. Purchart, L.; Tuf, I.H.; Hula, V.; Suchomel, J. Arthropod assemblages in Norway spruce monocultures during a forest cycle-A multi-taxa approach. For. Ecol. Manag. 2013, 306, 42-51. [CrossRef] 
36. Mihál, I.; Černecká, L. Structure of Harvestmen (Arachnida, Opiliones) Communities in Different, Anthropically Disturbed Beech Ecosystems (Western Carpathians, Slovakia). Vestn. Zool. 2017, 51, 259-270. [CrossRef]

37. Cardoso, P.; Pekár, S.; Jocque, R.; Coddington, J. Global patterns of guild composition and functional diversity of spiders. PLoS ONE 2011, 6, e21710. [CrossRef] [PubMed]

38. Volungevičius, J.; Šimanauskienè, R.; Kažys, J.; Bukantis, A.; Baškytė, R.; Baltrūnas, V.; Česnulevičius, A.; Kavoliutė, F. Klimatas [Climate]. In Lietuvos Gamtiné Geografija; Klaipėdos Universiteto Leidykla: Klaipėda, Lithuania, 2013; pp. $53-87$.

39. Adamonytè, G.; Iršènaitè, R.; Motiejūnaitè, J.; Taraškevičius, R.; Matulevičiūtè, D. Myxomycetes in a forest affected by great cormorant colony: A case study in Western Lithuania. Fungal Divers. 2013, 13, 131-146. [CrossRef]

40. Ellenberg, H.; Weber, H.E.; Düll, R.; Wirth, V.; Werner, W.; Paulißen, D. Zeigerwerte von Pflanzen in Mitteleuropa. Scr. Geobot. 1991, 18, 1-248.

41. Šilhavý, V. Sekáči-Opilionides. In Klič Zvířeny ČSSR 4; Daniel, M., Černý, V., Eds.; Academia Praha: Prague, Czech Republic, 1974; pp. 33-49.

42. Kaczmarek, J. Pareczniki Polski; Uniwersytet Adama Mickiewicza: Poznań, Poland, 1979.

43. Uddström, A.; Rinne, V. Suomen Lukit ja Valeskorpionit (Finish Harvestmen and Pseudoscorpions); Hyönteistarvike Tibiale Oy: Helsinki, Finland, 2016.

44. Nentwig, W.; Blick, T.; Bosmans, R.; Gloor, D.; Hänggi, A.; Kropf, C. Spiders of Europe, Version 03.2021. Available online: https:/ / www.araneae.nmbe.ch (accessed on 3 October 2021).

45. World Spider Catalog, Version 21.5. Natural History Museum Bern. 2021. Available online: http://wsc.nmbe.ch (accessed on 1 October 2021).

46. Kury, A.B.; Mendes, A.C.; Cardoso, L.; Kury, M.S.; Granado, A.A.; Yoder, M.J.; Kury, I.S. WCO-Lite version 1.1: An online nomenclatural catalog of harvestmen of the World (Arachnida 2021, Opiliones) curated in TaxonWorks. Zootaxa 2021, 4908, 447-450. [CrossRef] [PubMed]

47. Bonato, L.; Chagas, A., Jr.; Edgecombe, G.D.; Lewis, J.G.E.; Minelli, A.; Pereira, L.A.; Shelley, R.M.; Stoev, P.; Zapparoli, M. ChiloBase 2.0, 2016, A World Catalogue of Centipedes (Chilopoda). Available online: https:/ / chilobase.biologia.unipd.it (accessed on 15 December 2021).

48. R Core Team. R: A Language and Environment for Statistical Computing; R Foundation for Statistical Computing: Vienna, Austria, 2016.

49. Ter Braak, C.J.F.; Šmilauer, P. Canoco Reference Manual and User's Guide: Software for Ordination, version 5.0; Microcomputer Power: Ithaca, NY, USA, 2012.

50. Crawley, M.J. The R Book. In Chichester; John and Wiley and Sons: Hoboken, NJ, USA, 2012. [CrossRef]

51. Spungis, V. Fauna, distribution, habitat preference and abundance of harvestmen (Opiliones) in Latvia. Latv. Entomol. 2018, 45, $14-24$.

52. Žółkos, K.; Meissner, W. The effect of grey heron (Ardea cinerea L.) colony on the surrounding vegetation and the biometrical features of three undergrowth species. Pol. J. Ecol. 2008, 56, 65-74.

53. Korobushkin, D.I.; Saifutdinov, R.A. Influence of seabird colonies on soil macrofauna communities at the Black Sea coast forests. Russ. J. Ecol. 2019, 50, 567-573. [CrossRef]

54. Polis, G.A.; Hurd, S.D. Extraordinarily high spider densities on islands-flow of energy from the marine to terrestrial food webs and the absence of predation. Proc. Natl. Acad. Sci. USA 1995, 92, 4382. [CrossRef]

55. Jabin, M.; Topp, W.; Kulfan, J.; Zach, P. The distribution pattern of centipedes in four primeval forests of central Slovakia. Biodivers. Conserv. 2007, 16, 3437. [CrossRef]

56. Buchar, J.; Růžička, V. Catalogue of Spiders of the Czech Republic; Peres: Prague, Czech Republic, 2002. 